\title{
Varicella Pneumonia in Adults
}

Key words: varicella pneumonia, varicella-zoster virus, chickenpox, acyclovir

Varicella (chickenpox) is a common contagious infection caused by varicella-zoster virus with a benign outcome in children. However, pneumonia is the major and most frequent complication of varicella in healthy adults, with incidences being reported as high as $50 \%(1,2)$ and carries an overall mortality rate of between 10 and $30 \%$ (3). It has been reported that the susceptibility of varicella pneumonia in healthy adults is 25-fold greater than in children (4). Mortality rates approach $50 \%$ in patients who experience respiratory failure which requires mechanical ventilation, despite appropriate supportive and aggressive therapy (5). Smoking $(2,6)$ and pregnancy $(7,8)$ are well-known as risk factors linked to the development of varicella pneumonia in adults. Pregnancy may be related to severe varicella pneumonia (8). Patients with chronic lung disease are also at risk of manifesting varicella pneumonia (9). In immunocompromised hosts, such as human immunodeficiency virus-infected patients (10) and renal allograft recipients (11), the complication by varicella pneumonia is associated with a higher mortality rate.

Varicella pneumonia typically develops within 1-6 days after the onset of rash with symptoms of cough, dyspnea, chest tightness, fever and occasionally with chest pain and hemoptysis. In a limited number of cases, pulmonary symptoms may be present before the appearance of the skin rash (2). Patients demonstrate impaired gas exchange with progressive hypoxemia. Except for the hypoxemia, physical signs are a poor guide of severity (12). Chest radiographs typically reveal diffuse nodular opacities, progressing to extensive air-space consolidation (13). Nodular opacities tend to coalesce in the hilar regions and lung bases although they are usually fairly discrete in the lung periphery (14). Nodular opacities may resolve leaving calcific densities (15). Hilar adenopathy may also be present as well as pleural effusion, which is uncommon and rarely prominent. The pulmonary lesions caused by acute varicella infection consist of endothelial damage in small blood vessels, with focal hemorrhagic necrosis, mononuclear infiltration of alveolar walls and fibrinous exudates with macrophages in the alveoli, which contain eosinophilic intranuclear inclusions (14).

Since severe varicella pneumonia is relatively uncommon in adults, there have been no randomized controlled trials of antiviral therapy in the treatment of varicella pneumonia or even in the prevention of pneumonia in varicella infection. However, intravenous acyclovir appears effective against varicella pneumonia in previously healthy adults if started early (16) as in the case in this issue (17). In this case of a previously healthy young adult with severe varicella pneumonia that was complicated by acute respiratory distress syndrome (ARDS), rabdomyolysis, hepatitis and disseminated intravascular coagulation, treatment was successful with acyclovir and corticosteroids in addition to mechanical ventilation and hemofiltration.

See also p 1205.

The use of corticosteroids as adjunctive therapy for the treatment of life threatening varicella pneumonia is controversial and has not been well-studied. An uncontrolled study evaluating 15 adult patients with varicella pneumonia suggested that corticosteroids may reduce the period of hospitalization and the mortality rate (18). Regarding hemofiltration, there is a case report suggesting its efficacy for severe varicella pneumonia complicated by septic ARDS (19).

In conclusion, prompt administration of acyclovir and corticosteroids, in combination with mechanical ventilation, may be of benefit as a treatment for severe varicella pneumonia occurring in adults, which is complicated by ARDS and multiple organ dysfunction.

$$
\begin{array}{r}
\text { Takeshi KANEKO, MD, PhD } \\
\text { and Yoshiaki ISHIGATSUBO, MD, PhD } \\
\text { Department of Internal Medicine and Clinical Immunology, } \\
\text { Yokohama City University Graduate School of Medicine, } \\
\text { 3-9 Fukuura, Kanazawa-ku, Yokohama 236-0004 }
\end{array}
$$

\section{References}

1) Mermelstein RH, Freireich AW. Varicella pneumonia. Ann Intern Med 55: 456-463, 1961

2) Mohsen AH, Peck RJ, Mason Z, Mattock L, McKendrick MW. Lung function tests and risk factors for pneumonia in adults with chickenpox. Thorax 56: 796-799, 2001.

3) Triebwasser JH, Harris RE, Bryant RE, Rhoades ER. Varicella pneumonia in adults. Report of seven cases and a review of literature. Medicine (Baltimore) 46: 409-423, 1967.

4) Varicella-zoster immune globulin for the prevention of chickenpox. Morb Mortal Wkly Rep 33: 84-90, 1984.

5) Feldman S. Varicella-zoster virus pneumonitis. Chest 106 (Suppl): 22S-27S, 1994

6) El-Daher N, Magnussen R, Betts RF. Varicella pneumonitis: clinical presentation and experience with acyclovir treatment in immunocompetent adults. Int J Infect Dis 2: 147-151, 1998.

7) Ali ME. Varicella zoster during pregnancy: a strategy for prevention. J 
Obstet Gynaecol 21: 17-20, 2001.

8) Esmonde TF, Herdman G, Anderson G. Chickenpox pneumonia: an association with pregnancy. Thorax 44: 812-815, 1989.

9) Ong EL, Mulvenna P, Webb KA. Varicella-zoster infection in adults with cystic fibrosis: role of acyclovir. Scand J Infect Dis 23: 283-285, 1991.

10) Popara M, Pendle S, Sacks L, Smego RA Jr, Mer M. Varicella pneumonia in patients with HIV/AIDS. Int J Infect Dis 6: 6-8, 2002.

11) Fehr T, Bossart W, Wahl C, Binswanger U. Disseminated varicella infection in adult renal allograft recipients: four cases and a review of the literature. Transplantation 73: 608-611, 2002.

12) Hockberger RS, Rothstein RJ. Varicella pneumonia in adults: a spectrum of disease. Ann Emerg Med 15: 931-934, 1986.

13) Fraser RS, Muller NL, Colman N, Pare PD. Fraser and Pare's Diagnosis of Diseases of the Chest. 14th ed. W. B. Saunders, Philadelphia, 1999: 999-1004.

14) Sargent EN, Carson MJ, Reilly ED. Roentgenographic manifestations of varicella pneumonia with postmortem correlation. Am J Roentgenol Radium Ther Nucl Med 98: 305-317, 1966.

15) Raider L. Calcification in chickenpox pneumonia. Chest 60: 504-507, 1971.

16) Haake DA, Zakowski PC, Haake DL, Bryson YJ. Early treatment with acyclovir for varicella pneumonia in otherwise healthy adults: retrospective controlled study and review. Rev Infect Dis 12: 788-798, 1990.

17) Lee $\mathrm{S}$, Ito $\mathrm{N}$, Inagaki $\mathrm{T}$, et al. Fulminant varicella infection complicated with acute respiratory distress syndrome, and disseminated intravascular coagulation in an immunocompetent young adult. Intern Med 43: 1205-1209, 2004.

18) Mer M, Richards GA. Corticosteroids in life-threatening varicella pneumonia. Chest 114: 426-431, 1998

19) Gotloib L, Barzilay E, Shustak A, Waiss Z, Lev A. Hemofiltration in severe septic adult respiratory distress syndrome associated with varicella. Intensive Care Med 11: 319-322, 1985. 